\title{
A note on transhumant pastoralism in Niti valley, Western Himalaya, India
}

\author{
Monideepa Mitra', Amit Kumar ${ }^{1}$, Bhupendra S Adhikari ${ }^{1 *}$ and Gopal S Rawat ${ }^{2}$
}

\begin{abstract}
Pastoralism plays an important role in the ecology of alpine habitats and the economy of rural people in some regions of India. The pastoralists move from lower altitudes of the Himalayas to higher alpine regions in summer and return back to lower altitude villages with the onset of autumn. The forested areas along the routes of transhumant pastoralists are affected by anthropogenic pressures, viz. grazing by livestock and tree lopping by the herders for fuelwood. To demarcate such areas and evaluate the effect of anthropogenic disturbances, a preliminary documentation of the routes is needed. Interviews were conducted using semi-structured questionnaires to elucidate the information from herders visiting Niti valley, Western Himalayas. The interviews found that most of these herders had common stopovers following a similar route to the valley from their respective villages. More than $70 \%$ of herders made their transit camps at Niti village and adjoining areas. They stay there for a few days and then the majority move on to higher alpine pastures of Geldung. The rest either stay back at alpine areas near Niti or in the alpine areas adjoining Gamsali village. These stopovers are areas which experience maximum anthropogenic pressure during livestock migrations, and the vegetation is the most affected. Documentation of migration routes will help identify such areas of high pressure and develop management plans to minimize the disturbances.
\end{abstract}

Keywords: Niti valley; Pastoralists; Transhumance; Western Himalaya

\section{Methods}

A reconnaissance survey was undertaken to gather information regarding the number of migratory pastoral groups and the location of their summer tents. Information on their location was also obtained from official sources, e.g. village headman and Indo Tibetan Border Police (ITBP) officials.

In the present study, all of the eight shepherd groups visiting in the study area were interviewed. Within each shepherd group managing an average of 600 to 800 livestock, two to three people were interviewed. Out of total 27 adults, 16 individuals were interviewed. Semi-structured questionnaires were used to gather information regarding their herd composition, the routes they take and the utility of the animals they rear.

\footnotetext{
* Correspondence: adhikaribs@wii.gov.in

'Department of Habitat Ecology, Wildlife Institute of India, P.B. \#18, Chandrabani, Dehradun 248001, India
}

Full list of author information is available at the end of the article

\section{Findings}

Transhumant pastoralism

Transhumance - derived from the Latin word transhumare, trans meaning traverse and humus meaning earth was a term originally used to describe the pattern of human movement in the mountainous areas of Europe's alpine regions (Johnson 1969). According to Bhasin (2011), the nomadic pastoralists of Himalaya region make efficient use of the seasonally abundant natural resources, and their migration upholds soil fertility by generating organic manure from livestock, while grazing also controls spread of invasive plant species. Transhumant pastoralists' traditional practices of spending winters in lower regions and summers in the high alpine region help to conserve vegetation by alternating seasonal locations of grazing. Pastoralists have an important role in India's economy in terms of food security (mainly milk) and provision for draught animal, as well as foreign exchange (meat and fibre, e.g. pashmina (cashmere)) (Bhasin 2011).

\section{穴 Springer}

(C) 2013 Mitra et al.; licensee Springer. This is an Open Access article distributed under the terms of the Creative Commons Attribution License (http://creativecommons.org/licenses/by/2.0), which permits unrestricted use, distribution, and reproduction in any medium, provided the original work is properly cited. 
The adverse effects of grazing pointed out by earlier studies can be summarized as overgrazed pastures, eroded lands and proliferating weeds (Casimir and Rao 1985; Shah 1988; Rawat and Uniyal 1993). While passing through forests on their way to alpine areas, the transhumant herds adversely affect the regeneration of the forests (Pirazizy 1992), destroy crops (Chatterjee 1989; Awasthi 2001) and sometimes create or increase humanwildlife conflicts or competition between livestock and wildlife in alpine meadows (Mishra 1997; Mishra et al. 2004; Bagchi et al. 2004).

Hence, the objective of this study is to generate baseline information regarding the transhumant pastoralists that visit the study area, information which could be instrumental in demarcating such areas of high transhumant pastoral activity. This information can be utilized by the Forest Department for management of forests and pasture for maintaining records of the number of herds that use the area, their effect on vegetation regeneration, etc.; and design of further studies relating to the quality of those forested areas.

\section{Niti valley and transhumant pastoralism}

During the summer months, the transhumant pastoralists are scattered in the entire alpine regions of the Western Himalayas (for example, Bedni, Ali, Dyara, Gidara, Sahstratal, Auli, Rudranath, Pindari and Chhiplakedar in Uttarakhand state), except for the alpine regions of Protected Areas.

Niti valley (Figure 1) is situated in the TransHimalayan zone of Nanda Devi Biosphere Reserve (NDBR) in Uttarakhand state, containing seven migratory villages (Kailashpur, Mahergaon, Gurgutti, Farkia, Bampa, Gamsali and Niti). The migratory villagers have two permanent settlements: one winter settlement in the lower elevation and one upper-altitude summer settlement, i.e. Niti valley. The settled villagers in the NDBR belong to the Bhotiya tribe. These villagers are traditionally involved in activities such as cleaning and spinning of wool and weaving woollen items like shawls, pullovers, carpets, panki (blanket) and jackets, along with small-scale agriculture. Nowadays, they do not keep livestock and hence buy the raw material for making woollen items from the transhumant herders. These transhumant herders are generally people who belong to the lower elevations of the Himalayas, whose main occupation is to rear livestock and small-scale agriculture. They bring their herds to higher alpine meadows during summers for grazing. During the summer of June to August in 2012, eight such migratory pastoralist groups visited Niti valley study area. All the groups visiting the area have to furnish their personal details, i.e. about their herd composition, their duration and location of stay to the (ITBP) officials at Ghamsali check post as well as to the headman of the villages, as the Niti valley is on the border between India and China.

Each migratory shepherd group comprises three to five persons, all males, along with three to four horses/mules and three to four dogs (Tibetan mastiff, a breed of the high-altitude region). The shepherds within one group may or may not be family members. They are persons from the same village who bring their herds together for summer grazing. Each shepherd does not stay permanently for the whole grazing season of four to five summer months; instead, two or three shepherds take turns to rear the animals, while the others go back to their families. Sometimes, they also bring the livestock belonging to richer people who are not involved in livestock grazing and would often give these shepherds their animals to be taken up to the alpine meadows during summer, in return for money.

These shepherds are natives of Chamoli district in Uttarakhand state, India. The shepherds came from different villages in Chamoli district: Ghat (50\%), Pana (25\%), Ramni (12.5\%) and Birahi (12.5\%). They have permanent settlements in these villages and are involved in agriculture. Usually, one or two male members of the family moves out from the village with the herd over summer to the alpine region, while the rest of the family stays back, taking care of the crops. The same shepherd group may visit the same area every year, and the selection of summer grazing area is mainly based on their assessment of the quality of fodder and area available. The shepherds avoid overcrowding, i.e. one alpine meadow is usually occupied by one shepherd group.

The shepherd groups visiting the area in 2012 were mainly from Chamoli district (seven groups), and one group was from Nainital district of Uttarakhand state, India. They carry adequate clothing and camping accessories to support themselves during the journey as well as for the alpine regions.

The total number of livestock with these eight herder groups was 5,777, of which $65 \%$ were sheep and 35\% goats. The sheep are reared for wool as well as meat, while goats are an important source of meat and, to a lesser extent, for their rough wool (the long outer body hair) used to make rope and handicrafts. Horses and mules form $1 \%$ and $0.2 \%$ of the migratory livestock population, respectively, and are used primarily for carrying burdens. Each herder group keeps three to four dogs for the safety of livestock, protection from wild animals such as common leopard, wolf and jackal in the lower regions, and snow leopard and feral dogs in the alpine regions.

During their stay in the valley, the shepherds use the available natural resources of the area at a nominal price. The price, locally known as charan, is paid to village panchayat (an institution of self-government for the rural areas). Charan is paid according to the number and kind of animals of the herders' groups. The average charan 


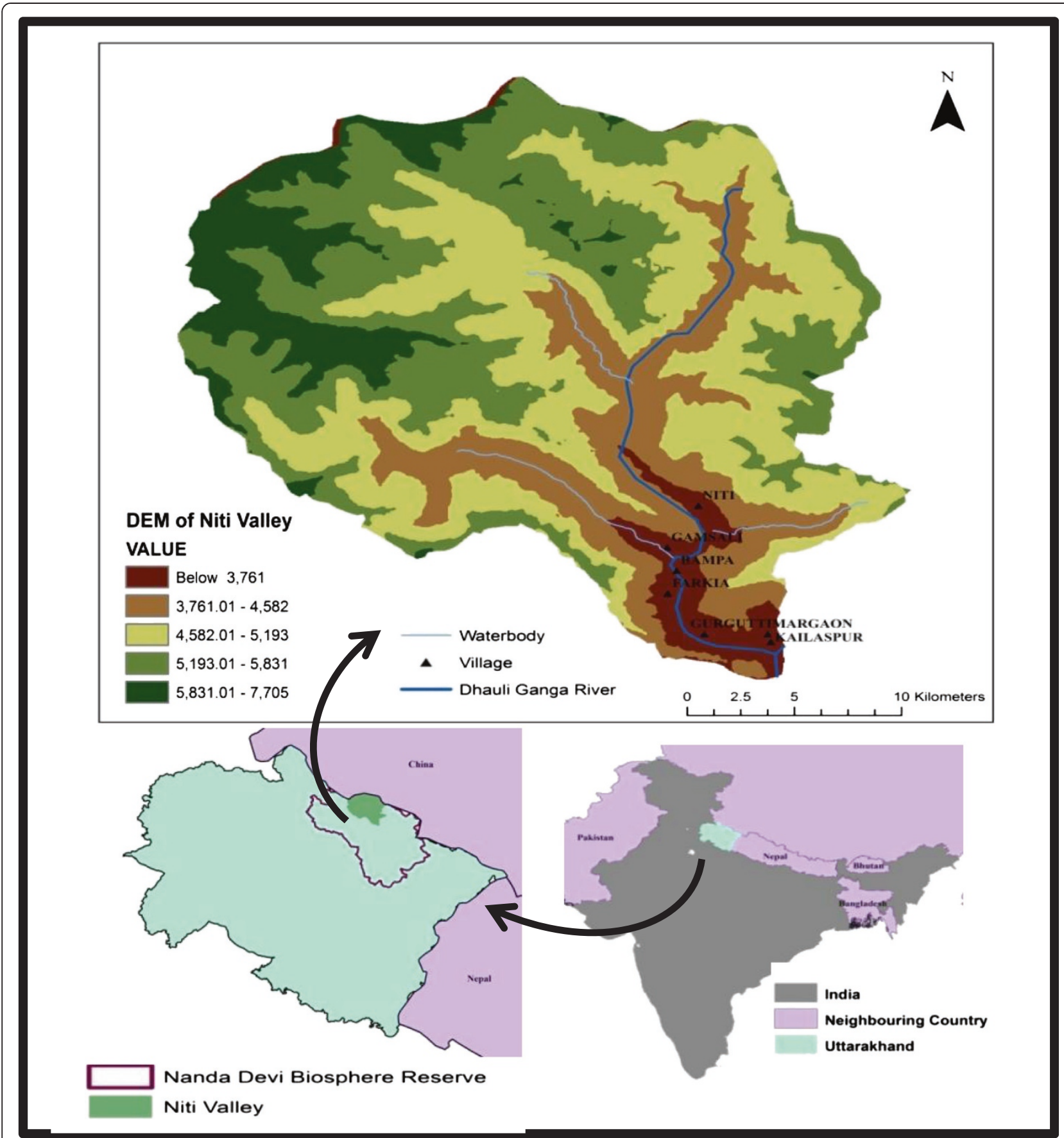

Figure 1 Map showing Niti valley (Upper Dhauli Valley) in Nanda Devi Biosphere Reserve (map not to scale). DEM, digital elevation model; values are given in metres.

is INR 5.62 (US\$0.10) per sheep/goat and INR 70.62 (US\$1.3) per horse/mule for the whole season.

The shepherd giving charan to panchayat of Gamsali village stays at an adjoining alpine area locally known as Dhaman payar. In the year 2012, only one such shepherd group occupied the Dhaman payar. Shepherds, who paid charan to the Niti village panchayat, spend their summers in areas locally known as Kalajowar, Gothing and Geldung areas. Of the shepherds, $70 \%$ halt at Niti before moving on to the Kalajowar, Gothing or Geldung area. They buy their food rations here, since Niti is the last village on the Indian side on this route. Geldung area, with an elevation range from 4,400 to $5,500 \mathrm{~m}$, has three mountain passes where these shepherds go for grazing: Niti pass, Lepcha pass and 


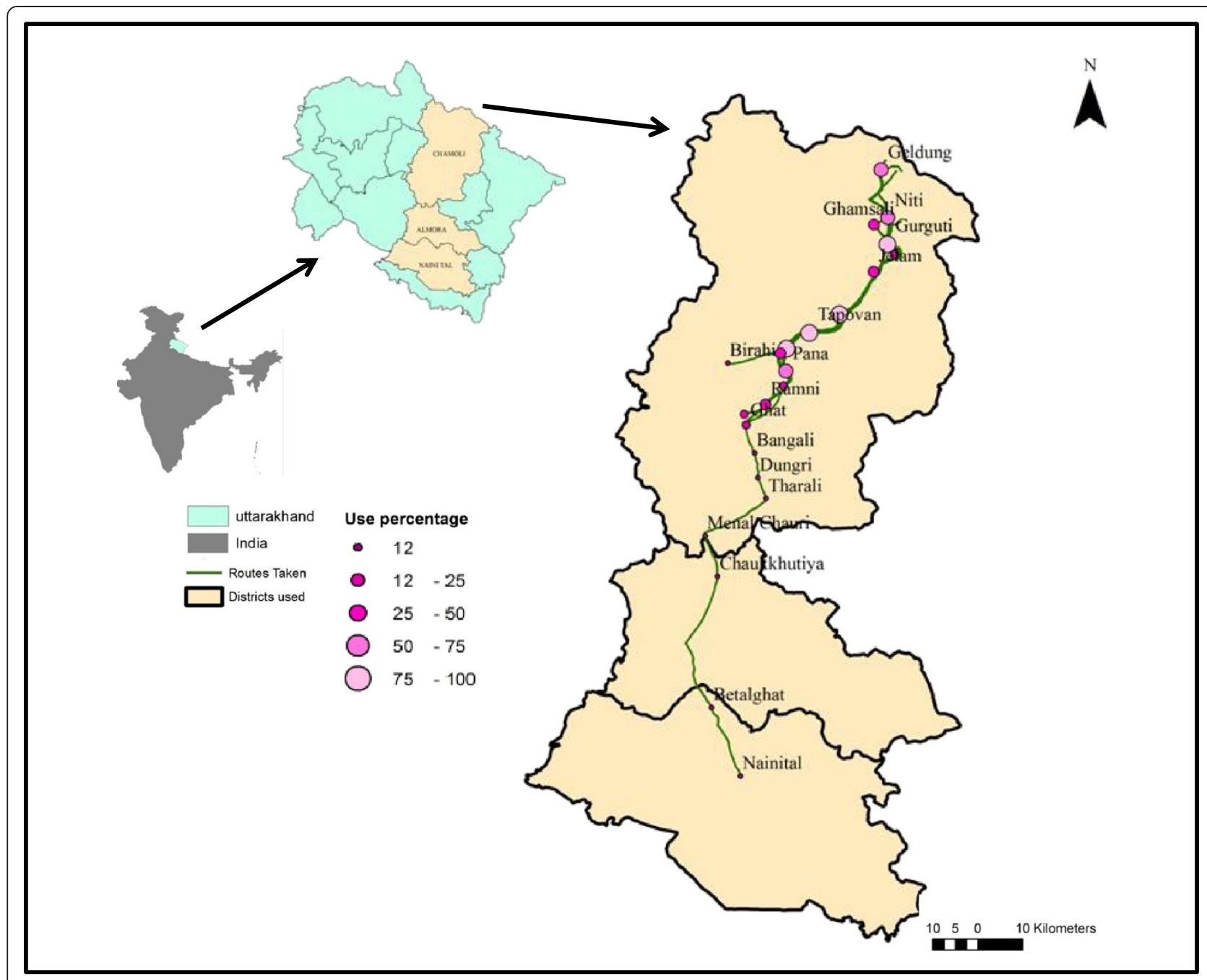

Figure 2 Percent use of different places and routes followed by transhumant herders visiting the Niti valley. The different places and routes based on interviews conducted. Map not to scale. Use percentage is the percentage of herders using a place.

Selakang pass. Other than these passes, a few shepherds (one or two groups) also tend to stay in adjoining areas locally known as Laldhang and Keolangmandi.

For sustenance while they are in the alpine valley, the shepherds sell sheep and goats to the resident local villagers which they buy to sacrifice during religious ceremonies and sometimes only for meat. The shepherds also sell wool to the villagers, and sometimes part of charan is paid in the form of wool. The price of wool per kilogram varies from INR 20 to INR 45 (US\$0.37 to US $\$ 0.83$ ), with an average cost of INR 36 (US\$0.67) per kilogram. Usually, black-coloured wool fetches a higher price (up to INR 46 (US\$0.85) per kilogram as compared to white- or grey-coloured wool. The black-coloured wool is preferred by the buyers as no money is spent for dyeing, and it is preferred by the buyers for making pakki (a type of local garment for the women). The shepherds start their return down to their villages in late August to early September, using the same route as on the way up.

The duration of their stay in Niti valley depends on the availability of fodder and mainly on climatic conditions, namely precipitation. Generally, the shepherds stay in the valley for three to four months, from late June to August. Over their usual stay and during their movement from plains to alpine regions and back, the shepherds come across many challenges, such as killing of livestock by wild carnivores (e.g. leopards), rains, landslides and occasional encounters with thugs.

There are various environmental issues linked with grazing, fodder and firewood collection from the forests. Moreover, there is an increasing danger of human-wildlife conflict due to habitat fragmentation and destruction by humans, and resource competition, as the forests and alpine meadows provide habitat to many wild mountain 


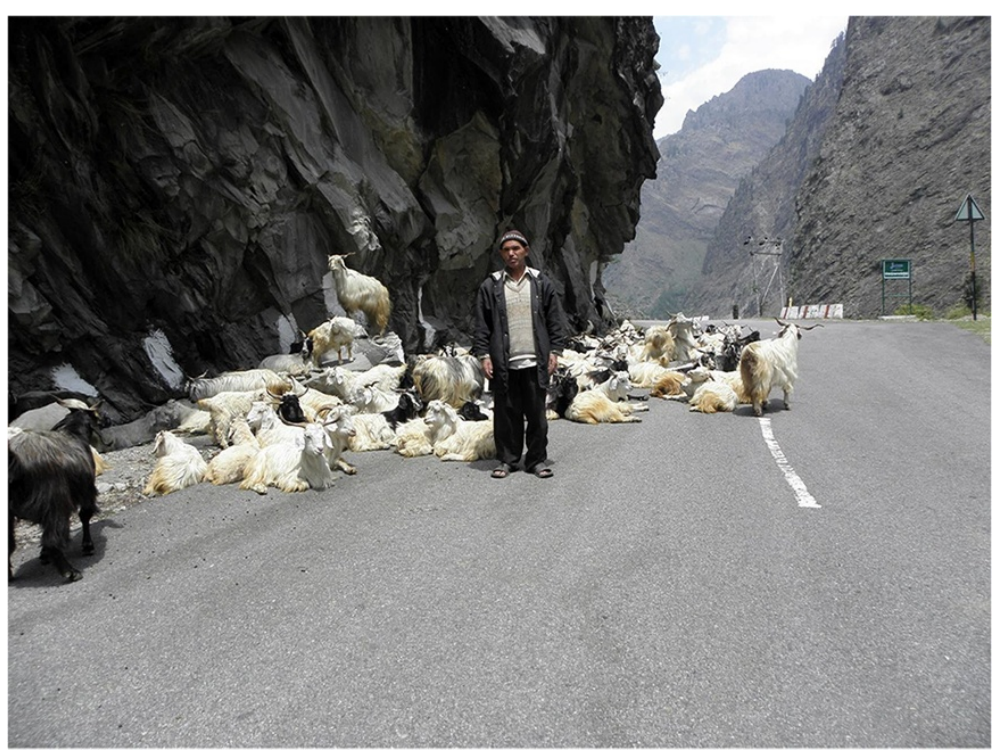

Figure 3 A flock of goats resting on the highway in day time. They move in the evening through villages just to avoid conflicts.

ungulates and carnivores including bharal (Pseudois nayaur), Himalayan tahr (Hemitragus jemlahicus), leopard (Panthera pardus) and snow leopard (Uncia uncia).

\section{Stopovers and routes}

The areas which experience maximum grazing pressure due to transhumant pastoralists are Kuari pass and Tapovan (Figure 2). Kuari pass $(3,640 \mathrm{~m})$ is a junction where most of the shepherds from lower altitudes camp for a few days to rest and then disperse to different alpine areas. Tapovan, a small town, is the last permanent village on the route to Niti valley. It acts as a congregation place where the shepherds replenish their stocks, as well as gather information regarding the status of alpine regions and the courses taken by other shepherds. They also do business with the local villagers by selling their animals. Shepherds take the motor road from Tapovan to their summer camps (Figure 3) and halt at several places at night. The routes taken by the eight shepherds and the use percentage of different stopovers are indicated in Figure 2.

\section{Conclusion}

Our findings suggest that Tapovan and Kuari pass are preferred stopovers for pastoralist groups migrating to the Niti valley during summer. Hence, there is a chance that these areas are comparatively more affected due to grazing, trampling and tree lopping by these transhumant pastoralists. These areas also serve as potential markets for the transhumant pastoralists, where they can sell their animals and animal-derived products like wool to the local inhabitants.

The documentation of routes on maps and details of transhumant pastoralists' activities can help identify such areas for further studies, to understand the current status and future impact of transhumant pastoralism in this region.

\section{Competing interests}

The authors declare that they have no competing interests.

\section{Authors' contributions}

$\mathrm{MM}$ and $\mathrm{AK}$ contributed to the collection of data through questionnaire surveys, analysis of data and writing the manuscript; BSA and GSR contributed to the design of questionnaire forms, analysis and interpretation of data and reviewed the manuscript. All authors read and approved the manuscript.

\section{Acknowledgments}

The authors acknowledge the support of Ministry of Environment and Forests, New Delhi, India for funding this study. The authors wish to acknowledge the Director, Wildlife Institute of India (WII), Dehradun and Dean, Faculty of Wildlife Sciences, WII for providing necessary facilities and Uttarakhand State Forest Department for granting permission to work in the remote area. The authors acknowledge Ms. Samhita Bose for her help in GIS, Shri Amar Gamswal for assisting in field. Sincere appreciation goes to the pastoralists for their cooperation and help.

\section{Author details}

${ }^{1}$ Department of Habitat Ecology, Wildlife Institute of India, P.B. \#18, Chandrabani, Dehradun 248001, India. ${ }^{2}$ Environment Change and Ecosystem Services, ICIMOD, Lalitpur G.P.O. Box 3226, Kathmandu, Nepal.

Received: 27 September 2013 Accepted: 25 October 2013 Published: 02 Dec 2013

\section{References}

Awasthi, A. 2001. Ecological Impact of anthropogenic pressures on high altitude forests along Bhagirathi Catchment. Ph. D Thesis. Dehradun: FRI Deemed University.

Bagchi, S, C Mishra, and YV Bhatnagar. 2004. Conflicts between traditional pastoralism and conservation of Himalayan ibex (Capra sibirica) in the Trans-Himalayan mountains. Animal Conservation 7: 121-128. doi:10.1017/ S1367943003001148.

Bhasin, V. 2011. Pastoralists in India. Journal of Human Ecology 33(3): 147-177. 
Casimir, MJ, and A Rao. 1985. Vertical control in the Western Himalaya: Some notes on the pastoral ecology of the nomadic Bakerwal of Jammu and Kashmir. Mountain Research and Development 5(3): 221-232.

Chatterjee, PC. 1989. Nomadic graziers of Garhwal. In Studies in Himalayan Ecology and developmental strategies. Singh, T.V. and J. Kaur (eds.), New Delhi: Himalayan Books. pp: 93-99.

Johnson, DL. 1969. The nature of nomadism: A comparative study of pastoral migrations in South-Western Asia and Northern Africa, vol. 8, 118th ed, 200. Chicago: Department of Geography, University of Chicago.

Mishra, C. 1997. Livestock grazing and wildlife conservation in the Indian transHimalaya: A preliminary survey. Report for the Wildlife Conservation Society, New York. Mysore: Centre for Ecological Research and Conservation.

Mishra, C, SE Van Wieren, P Ketner, IMA Heitkönig, and HHT Prins. 2004. Competition between domestic livestock and wild bharal Pseudois nayaur in the Indian Trans-Himalaya. Journal of Applied Ecology 41: 344-354. doi:10.1111/j.0021-8901.2004.00885.x.

Pirazizy, AA. 1992. Man and Environment, Himachal Himalayan perspectives: Shimla, 155-174. Shimla: Minerva Book House.

Rawat, GS, and VK Uniyal. 1993. Pastoralism and plant conservation: The valley of flowers dilemma. Environment Conservation 20(2): 164-167.

Shah, MH. 1988. Role of nomads in the destruction of alpine and sub alpine pastures and future strategies. In Rangelands: Resource and management, ed. P Singh and PS Pathak, 148-152. Jhansi, India: Range Management Society of India.

10.1186/2041-7136-3-29

Cite this article as: Mitra et al:: A note on transhumant pastoralism in Niti valley, Western Himalaya, India. Pastoralism: Research, Policy and Practice 2013, 3:29

\section{Submit your manuscript to a SpringerOpen ${ }^{\circ}$ journal and benefit from:}

- Convenient online submission

- Rigorous peer review

- Immediate publication on acceptance

- Open access: articles freely available online

- High visibility within the field

- Retaining the copyright to your article

Submit your next manuscript at $\gg$ springeropen.com 